\title{
Development of a SCAR Marker Linked to Male Fertility Traits in 'Jinkyool' (Citrus sunk)
}

\author{
Chi Won Chae ${ }^{1}$, Manjul Dutt ${ }^{2}$, Su Hyun Yun ${ }^{1}$, Jae Ho Park ${ }^{1}$ and Dong Hoon Lee ${ }^{1}$ * \\ ${ }^{1}$ Citrus Research Station, National Institute of Horticultural \& Herbal Science, Rural Development Adtministration, Jeju 699-946, Korea \\ ${ }^{2}$ Citrus Research and Ecucation Center, University of Florida/FAS, 700 Experiment Station Road, Lake Alfred, FL 3385, USA
}

Received September 2, 2011 /Revised December 12, 2011 /Accepted December 13, 2011

\begin{abstract}
In Citrus, an $\mathrm{F}_{1}$ segregation population of 150 plants was constructed from a cross between 'Kiyomi' $(C$. unshiu $\times$ C. sinensis) carrying the male sterility trait and 'Jinkyool' (C. sunk). Sequence-related amplification polymorphism (SRAP) combined with bulked segregant analysis was used to develop markers linked to male fertility. In the $F_{1}$ population, 66 out of 150 seedlings had aborted anthers and the ratio of male sterile plants to fertile plants in the progenies matched the expected Mendelian segregation ratio of $1: 1\left(\mathrm{x}^{2}=2.16\right.$ at $\left.p=0.05\right)$. From the profiling of the $197 \mathrm{SRAP}$ primer sets, three SRAP primer sets (F4/R27, F39/R60, and F15/R37) that were closely linked to the target trait were identified and successfully converted into a sequence characterized amplified region (SCAR) marker for selection of male fertility in citrus. The SCAR marker, using the pMS 33U/pMS 1462L primer set specifically, produced a single $1.4-\mathrm{Kb}$ fragment that was linked to male fertility. Our results suggested that this SCAR marker can be useful for marker-assisted selection of male sterile individuals in breeding $\mathrm{F}_{1}$ progenies in Citrus.
\end{abstract}

Key words : Bulked segregant analysis, Citrus unshiu, male sterility, 'Satsuma' mandarin

\section{Introduction}

Citrus spp. at the diploid level produces seedy fruits by fertilization. The total number of seeds of almost all hybrids is less than the total ovules. Liu et al. [21] and Yamamoto et al. [44] showed that the average number of perfect seeds per citrus fruit was 0 to 62 due to a high genetic variation. Indeed, citrus fruit containing seeds is less acceptable to consumers in fresh fruit market since those seeds are the source of unfavorable aromatic compounds and bitterness in citrus juice [30]. Therefore, seedless hybrid is a very desirable trait for citrus growers, consumers, and related industries. The creation of sterile citrus cultivar producing seedless fruit may be one of the most important goals of citrus breeding programs.

In horticulture, parthenocarpic phenomenon induces naturally or artificially the production of fruit without fertilization of ovules. The citrus fruit is therefore seedless. Frost [10] assumed that various commercial citrus cultivars have some distinct degree of ovule or sterile pollens. Mukaku kishu-type seedless citrus is caused by arrested embryo de-

\footnotetext{
*Corresponding author

Tel : +82-64-730-4143, Fax : +82-64-733-9564

E-mail : chocho90@rda.go.kr
}

velopment due to the maternal tissues [45]. In 'Satsuma' and 'Encore' mandarins, anther abortion resulting in the production of sterile stamen and no viable pollen, is associated with cytoplasmic-genic male sterility and is probably controlled by more than 2 major genes $[25,41,43]$. Those accessions have frequently showed maternal heredity due to aborted anthers without being affected by unfavorable weather conditions, diseases and injuries by insects during microspore development $[4,6,22,27,37,41,43]$. In brassica [2], Nicotiana sylvestris [13], maize [19], petunia hybrid [28], radish [29], and sunflower [18], the production of unviable pollens are similarly controlled by the expression of specific genes. The male sterile lines [5] have the ability to produce seedless fruits when cross-pollination is blocked. At present, several famous commercial citrus cultivars in Korea, such as the 'Satsuma' mandarin and 'Kiyomi' progenies are generally seedless in monoculture. 'Kiyomi' tangor is predominant for easy peeling and marketable fruit quality. 'Kiyomi' tangor was produced from a combination of 'Satsuma' mandarin $\mathrm{cv}$. 'Miyagawa wase' and a sweet orange ( $C$. sinensis) cv. 'Trovita' [27]. When 'Kiyomi' tangor is used as the female parent, the progenies are phenotypically distinct from the aborted pollen or fertile pollen types $[15,24,25,26,42]$. Therefore, the distinct floral trait may be a key phenotype 
in the breeding of seedless citrus cultivars. However, a long juvenility of citrus is a limiting factor for developing seedless citrus cultivars in conventional breeding since it may take as long as $5-20$ years or longer $[1,9,32,34]$.

With rapid advances in biotechnology, various types of molecular marker such as random amplified polymorphic DNAs (RAPDs) [39], amplified fragment length polymorphisms (AFLPs) [38], and several other polymerase chain reaction (PCR)-based markers have been applied to improve the efficiency of conventional citrus breeding. Li and Quiros [20] have developed the sequence-related amplification polymorphisms (SRAP) to amplify intragenic sites carrying AT or GC rich cores by using specific sets of primers. SRAPs are simple to run, and provide a moderate throughput rate. This marker type also reveals many co-dominant alleles originated from, open reading frames (ORFs) and allows simple isolation of PCR products for cloning and sequencing. Recently, Uzun et al. [36] and Gulsen et al. [12] constructed a Citrus linkage map based on SRAP markers and found that these markers were evenly spread on citrus genome. However, for the ease of use and rapid detection, SRAP marker needs to be converted into simple sequence characterized amplified regions (SCARs) marker. Paran and Michelmore [31] developed SCARs by designing locus-specific oligonucleotide primers based on RAPDs.

Molecular markers tightly linked to an important trait can be useful for marker-assisted selection (MAS). In citrus, the advantage of MAS is its ability to identify potential sterile individuals at the seedling stage by using DNA markers tightly linked to sterility. MAS is especially advantageous when selecting for traits that are expressed only at later stages of development, such as floral characteristics. Until now there have been no reports for DNA markers linked to anther type in Citrus.

Bulked segregant analysis (BSA) is a simple procedure employed to efficiently profile markers joined with specific regions of the genome. Generally in BSA, two bulked DNA samples composed of individuals that show two contrasting phenotypes for a targeted trait are developed, and molecular markers that are polymorphic between these DNA samples are screened [23].

The present research was conducted identifying SRAP markers for male fertility by BSA, and to convert the SRAPs into a robust SCAR marker for efficient MAS of male fertility in 'Jinkyool' breeding programs.

\section{Materials and Methods}

\section{Plant materials}

One hundred-fifty $\mathrm{F}_{1}$ progenies from a cross of 'Kiyomi' (C. unshiu $\times$ C. sinensis $) \times$ 'Jinkyool' (C. sunk) $)$ were planted in the research orchard of the Citrus Experiment Station at the National Institute of Horticultural \& Herbal Science, Rural Development Administration, Korea in 1994. $F_{1}$ progenies carrying aborted anthers were visually chosen based on the phenotypic characteristics like shrinking and discoloration of anthers at full bloom stage in 2009.

\section{DNA extraction and preparation of bulked DNA}

Young and healthy leaf samples were collected from 23 trees which were distinguished by their aborted or fertile anthers. Total gnomic DNA (gDNA) was extracted using a plant tissue DNA preparation cartridge (AS1030, Promega Corp, Madison, WI, USA) and an automatic DNA extractor MX-16 (Compacbio Sciences Co., Korea). The quality and quantity of the gDNA were determined using Spectrometer libra S35 (Biochrom Ltd., UK). For BSA, two separate DNA pools were constructed which is composed of male aborted (23) and male fertile (23) plants.

\section{SRAP analysis}

SRAP analysis (197 primer combinations used) was con-

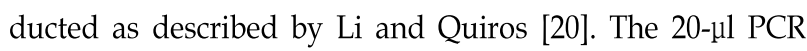
mixture was consisted of AccuPower PCR Premix (Bioneer, Daejen, Korea), containing $250 \mu \mathrm{M}$ dNTP, $1.5 \mathrm{mM} \mathrm{MgCl}_{2}$, 1.0 unit Taq DNA Polymerase, $10 \mathrm{mM}$ Tris- $\mathrm{HCl}$ (pH 9.0), $40 \mathrm{mM} \mathrm{KCl}$, and 50 pmol of each forward and reverse primer, as detailed in Table 1, and 25 ng template DNA. PCR amplification was carried out using a Takara PCR thermal cycler (Takara, Japan). The PCR conditions were as follows: an initial cycle at $94^{\circ} \mathrm{C}$ for $5 \mathrm{~min} ; 5$ cycles of $94^{\circ} \mathrm{C}$ for $1 \mathrm{~min}$; $35^{\circ} \mathrm{C}$ for $1 \mathrm{~min}$, and $72^{\circ} \mathrm{C}$ for $2 \mathrm{~min} ; 35$ cycles of $94^{\circ} \mathrm{C}$ for $1 \mathrm{~min} ; 50^{\circ} \mathrm{C}$ for $1 \mathrm{~min}$; and $72^{\circ} \mathrm{C}$ for $2 \mathrm{~min}$ and a final elongation temperature of $72^{\circ} \mathrm{C}$ for $10 \mathrm{~min}$ [35]. The amplified DNA products were loaded on a $1.2 \%$ agarose gel and stained with $0.5 \mathrm{\mu g} / \mathrm{ml}$ ethidium bromide.

\section{Conversion of SRAP marker into SCAR marker}

A target DNA fragment was amplified in all male fertile types by PCR with the primer set F39/R60. A single PCR band of approximately $1.5 \mathrm{~kb}$ fragment was extracted from the gel using a gel extraction kit (5212, Nucleogen Co., 
Table 1. Characteristics of the SRAP and SCAR markers linked to male fertility and detected by bulked segregant analysis

\begin{tabular}{|c|c|c|c|c|}
\hline Primer sets & Sequence $\left(5^{\prime}-3^{\prime}\right)$ & Anneal temp. $\left({ }^{\circ} \mathrm{C}\right)^{a}$ & Size $^{b}$ & Trait \\
\hline F4 (forward) & TGAGTCCAAACCGGAAT & \multirow{2}{*}{50} & \multirow{2}{*}{554} & \multirow{2}{*}{ Fertility } \\
\hline R27 (reverse) & GACTGCGTACGAATTCGG & & & \\
\hline F39 (forward) & TGAGTCCAAACCGGGCG & \multirow{2}{*}{50} & \multirow{2}{*}{1487} & \multirow{2}{*}{ Fertility } \\
\hline R60 (reverse) & GACTGCGTACGAATTTGT & & & \\
\hline F15 (forward) & TGAGTCCAAACCGGATG & \multirow{2}{*}{50} & \multirow{2}{*}{470} & \multirow{2}{*}{ Fertility } \\
\hline R37 (reverse) & GACTGCGTACGAATTGCA & & & \\
\hline pMS 33U (forward) & GGGCAAGTATCGCAACCCCTC & \multirow{2}{*}{53} & \multirow{2}{*}{1429} & \multirow{2}{*}{ Fertility } \\
\hline pMS 1462L (reverse) & CTTGAGAGGTGTAGTATAAGTG & & & \\
\hline
\end{tabular}

${ }^{a}$ The annealing temperature $\left({ }^{\circ} \mathrm{C}\right)$

${ }^{\mathrm{b}}$ Sizes of the polymorphic SRAP combinations and PCR products with the SCAR primer in base pairs

Korea) and cloned into Topo TA plasmid vector (K450001, Invitrogen Corp., Carlsbad, CA, USA). Escherichia. coli TOP10 was used for the cloning of the plasmid (C4040-03, Invitrogen Corp., Carlsbad, CA, USA). The cloned plasmid was extracted using Wizard ${ }^{\circledR}$ Plus SV Minipreps DNA purification system (A1460, Promega Corp., Madison, WI, USA). Nucleotide sequencing was performed using Bigdye ${ }^{\mathrm{TM}}$ Terminator Cycle Sequencing kits (PE Biosystems, Foster City, CA, USA) and an automated DNA sequencer (ABI 3100, Applied Biosystems, Rockville, MD, USA). Specific forward and reverse primer pairs for SCAR were designed and synthesized by Bioneer (Seoul, Korea) (Table 1). PCR with SCAR primers was performed with genomic DNA of the 'Kiyomi' $\times$ 'Jinkyool' population, and the amplified DNA fragment was visualized as described above.

\section{Results and Discussion}

\section{Phenotyping of male sterility and fertility}

Flowers of $150 \mathrm{~F}_{1}$ progenies were evaluated for the presence or absence of pollen in May, 2008 and 2009. The number of male sterile and male fertile $F_{1}$ progenies was 66 and 84, respectively. A chi-square "goodness of fit" of the observed segregation ratio were not significantly different from the expected Mendelian segregation ratio of $1: 1 \quad\left(x^{2}=2.16\right.$ at $p=0.05)$. Hybrid seedlings with aborted anthers and male fertile anthers, as were observed in our experiments, arise from crosses of cultivars which have the cytoplasm of 'Kiyomi' tangor as seed parents [42]. This result was consistent with a previous study on male sterility that used a different cross of 'Kiyomi' and 'Kuchinotsu No. 20' [43]. The determination of male fertility can be achieved through the observation of anthers [25]. This study indicates that phenotype of anther can be efficiently used as a morphological marker for selecting male fertile plants. However, it may take approximately 4 years to screen new seedless/seedy hybrids between aborted anther types and normal anther types by using this morphological marker. BSA allows widespread application of profile markers linked to genetic traits $[3,23]$. BSA was easy to construct two pooled DNA samples of individuals from two segregating populations (male sterility/male fertility) using 'Kiyomi' tangor as female parent. It was also the same with the separation of male sterility to fertility which fitted the expected 1:1 ratio when 'Kiyomi' tangor was used as female parent [28]. DNA markers linked to the seedless/seedy trait identified in Ponkan mandarin (C. reticulate Blaco) [40].

\section{SRAP markers linked to the male fertile trait by BSA}

Three (F4/R27, F39/R60, and F15/R37) (Table 1) out of 195 SRAP primer pairs produced markers that were potentially linked to the male fertile locus. These primer sets showed polymorphic PCR bands between the two DNA pools. The polymorphic bands were amplified from the bulked DNA sample for male fertile plants (Fig. 1). However, perfect cosegregation between the phenotype of 23 individuals and the polymorphic PCR band was detected only from the primer set F39/R60 (Fig. 2). The previous work of Michelmore et al. [23], the number of individuals comprising each bulk carried from 14 to 20 plants. In this study, the number of individuals consisted of each bulk (23 individuals) was recognized quite larger and more strict than usually used bulked individuals in the experiments to detect linked markers. With dominant markers such as SRAPs, more individuals would need to be combined to en- 


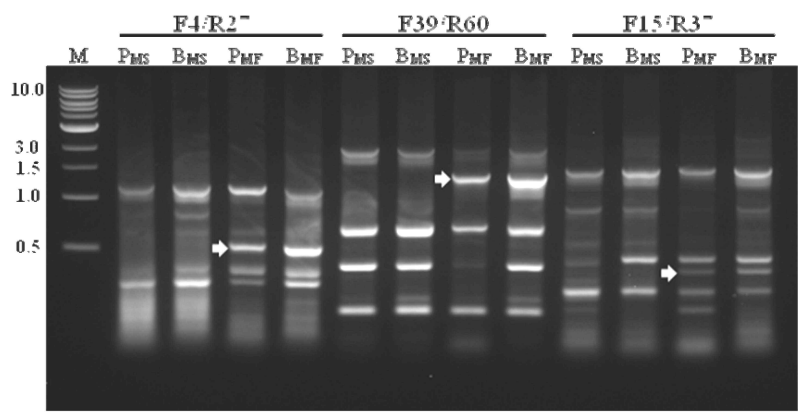

Fig. 1. Bulked segregant analysis with primers F4/R27, F39/R60 and F15/R37. $\mathrm{P}_{\mathrm{MS}}=$ male sterile parent, $\mathrm{P}_{\mathrm{MF}}=$ male fertile parent, $\mathrm{B}_{\mathrm{MS}}=$ male sterile bulk, and $\mathrm{B}_{\mathrm{MF}}=$ male fertile bulk. Primer combinations are indicated on top of the lanes. $\mathrm{M}=$ molecular weight marker (1 kbp ladder plus), Numbers on the left margin represent molecular weight markers in kb. Polymorphic bands are shown by the arrow.

sure it in the population as a whole.

\section{Sequence analysis of SRAP markers}

The male fertility-specific PCR band from the primer set F39/R60 was cloned and sequenced to be converted into a simple PCR-based SCAR marker. The resulting recombinant vector plasmids were amplified with the primer set F39/R60, and PCR products were examined on a sequencing gel to ensure that the correct target DNA fragments were inserted. The cloned DNA fragment was sequenced and found to be

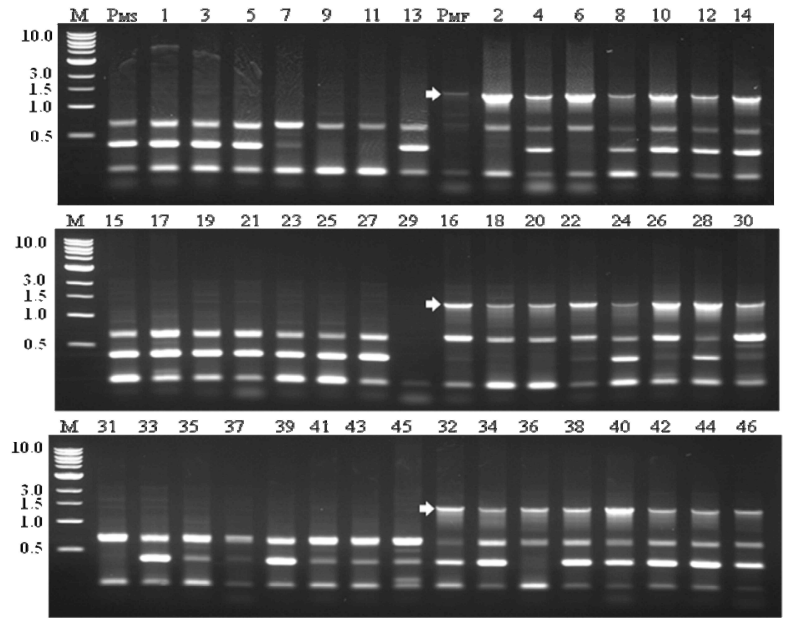

Fig. 2. Individual analysis of SRAP fragment F39/R60 in 'Kiyomi' $(C$. unshiu $\times$ C. sinensis $) \times$ 'Jinkyool' $(C$ sunk) F1 segregant populations. $\mathrm{M}=$ molecular weight marker $(1 \mathrm{kbp}$ ladder plus), $\mathrm{P}_{\mathrm{MS}}=$ male sterile parent, $\mathrm{P}_{\mathrm{MF}}=$ male fertile parent, odd numbers=male sterile F1 progenies, and even numbers=male fertile $\mathrm{F} 1$ progenies. Numbers on the left margin represent molecular weight markers in $\mathrm{kb}$. Arrows on the left margin indicate F39/R60 SRAP fragments.

1,487-bp in length (Fig. 3). This sequence is available in the NCBI GenBank database (Accession number, HM135404.1). Blastn analysis was performed based on the sequence data of the marker, and high homology $(99.0 \%)$ to 26 s ribosome RNA gene of $C$. aurantium and C. limon revealed (Fig. 3) [17].

1 TGAGTCCAAA CCGGGCGGGg GGCCTCCCGA GGGGGCAAGT ATCGCAACCC CTCTCGACGA

61 AACGgGAAAA ATAATGCGgG AgACCCTGGA CCCATTTTTC GGCCAAAAAG GGCCAAAATC

121 CTTGCGCCAA ATTTCGAGTT TTCGgGCCGG CGTGGGATTT TTGGCTGATA TTGTTAGCCA

181 CAGGCTCTTT GGCCAAATTT CGCCTTTGTG CCAGCCACTT AGATTTTGCA GAGAGTTAGC

241 CTCATGAAAA AGCACAAGTC CACTCCGAGG CCCGAGCTAG CCTCCTTTCG GAGCCATCAC 301 ACAAGTCTTT GTGCCAGAgT TAgCCTCAgG CATtgGAGCA AgTGTGCTGC CTTTGTGCCA 361 GCCACTTAGA TTTTGCCGAG AGTTAGCCTC GTGAAAAAAC ACAAGTCCAC TCCGAGCCTT 421 GgGCGGGGGC AgTCCGTGCG GGCGTGTGCG CCGCAGgGgG CTAACCTCCG GCGGGTTCCG

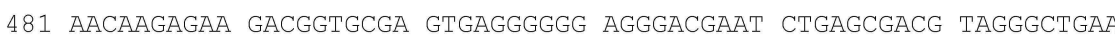
541 TCTCAGTGGA TCGTGGCAGC AAgGCCACTC TGCCACTTAC AATACCCCGT CGCGTATTTA 601 AgTCGTCTGC AAAgGATTCT ACCCGCCGCT CGATGgGAAT TACGATTCAA GgCGGCCGCC 661 GCGGCCCTTC CGCCGCGGgG GCTTGgCCTA CGACACGTGC CTCTGGGGAC CGGGAGGTCC 721 CTACTGCGGG TCGGCAAACG GGCGGCGGGC GCACGCGTCG CTCTAGCCCG GATTCTGACT 781 TAGAGGCGTT CAGTCATAAT CCAGCGCACG GTAGCTTCGC GCCACTGGCT TTTCAACCAA 841 GCGCGATGAC CAATTGTGCG AATCAACGGG TTCCTCTCGT ACTAGGTTGA ATTACTATTA 901 CGACGCAGTC ATCAGTANGT AAAACTAACC TGTCTCACGA CGGTCTAAAC CCAGCTCACG 961 TTCCCTATTG GTGGGTGAAC AATCCAACAC TTGGTGAATT CTGCTTCACA ATGATAGGAA 1021 GAGCCGACAT CGAAGGATCA AAAAGCAACG TCGCTATGAA CGCTTGGCTG CCACAAGCCA 1081 GTTATCCCTG TGGTAACTTT TCTGACACCT CTAGCTTCAA ATTCCGAAGG TCTAAAGGAT 1141 CGATAGGCCA CGCTTTCACA GTTCGTATTC GTACTGAAAA TCAGAATCAA ACGAGCTTTT 1201 ACCCTTTTGT TCCACACGAG ATTTCTGTTC TCGTTGAGCT CATCTTAGGA CACCTGCGTT 1261 ATCTTTTAAC AGATGTGCCG CCCCAGCCAA ACTCCCCACC TGACAATGTC TTTCGCCCGG 1321 ATCGgCCCCC GTGAgGgGgC CTTGgGTCCA AAAAGAGGgG CAgTGCCCCG CCTCCGATTC 1381 ACGGAATAAG TAAAATAACG TTAAAAGTAG TGGTATTTCA CTTTCGCCGT TTCCGGCTCC 1441 CACTTATACT ACACCTCTCA AGTCATTTCA CAAATTCGTA CGCAGTC

Fig. 3. Nucleotide sequence of the fertility-specific DNA fragment amplified with the SRAP F39/R60 primer. PCR-specific primer sequences of pMS 33U and pMS 1462L are indicated in rectangle boxes. The primer for gene amplification was synthesized according to the nucleotide sequence of SRAP F39/R60. The size of this gene fragment is 1,487 bp. 


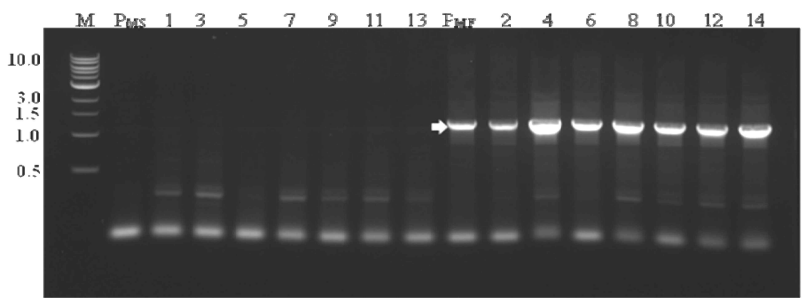

Fig. 4. Individual analysis of SCAR fragment pMS 33U/pMS 1462L in 'Kiyomi' (C. unshiu $\times$ C. sinensis $) \times$ 'Jinkyool' (C. sunk) $\mathrm{F} 1$ segregant populations. $\mathrm{M}=$ molecular weight marker (1 kbp ladder plus), $\mathrm{P}_{\mathrm{MS}}=$ male sterile parent, $\mathrm{P}_{\mathrm{MF}}=$ male fertile parent, odd numbers=male sterile $\mathrm{F} 1$ progenies, and even numbers=male fertile $\mathrm{F} 1$ progenies. Numbers on the left margin represent molecular weight markers in $\mathrm{kb}$. The arrow indicates SCAR fragments.

The homology of our SCAR marker sequence to 26s rRNA gene of $C$. aurantium and $C$. limon provided valuable information on the relationship between the genetic function of rRNA and anther development. Kolosha and Fodor [17] reported that 26s rRNA in $C$. limon was present in the alignment with the large rRNA sequences of Escherichia coli, Saccharomyces cerevisiae and Oryza sativa. High degree of rearrangement in the flanking or coding regions of the $26 \mathrm{~s}$ rRNA in Ogura mtDNA appeared to be a common feature of CMS plants in radish $[7,8]$. Therefore, a new transcriptional profiling study for the genic region of our SCAR marker sequence would be another interesting research subject.

\section{Conversion of SRAP marker into SCAR marker}

The SRAP marker F39/R60 was successfully converted into a simple SCAR marker (pMS33U/pMS 1462L) (Table 1). The individual $\mathrm{F}_{1}$ plants with aborted normal anthers were screened by this SCAR marker and robust and reproducible PCR results were obtained (Fig. 4). Furthermore, the SCAR marker was tested 12 different cultivars. The results showed that the presence of the SCAR marker (1,429 bp) in 'Jinkyool' carrying normal anthers as expected from the sequence data, but absence in other seedless cultivars that were developed as male sterile parent producing abnormal anthers (Fig. 5). SCAR marker provides with potential benefits over universal primers like RAPD in that these markers amplify specific sites of the genome and prevent site-competition among primers [16,31]. This, in turn, indicated that SCAR markers are less sensitive to the PCR conditions [14]. SCAR markers also permits rapid and reproducible sample assessment [11], since the markers are generally associated with the amplifi-

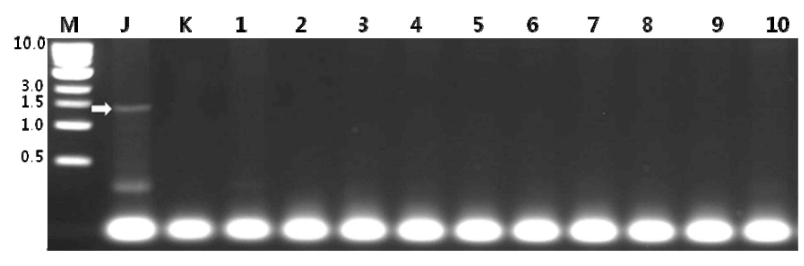

Fig. 5. Verification of SCAR marker linked to the normal anther in 'JinKyool'(J), and 'Kiyomi'(K), and male sterility of seedless citrus varieties, 'Miyagawa unshu'(1), 'Shiranuhi'(2), 'Setoka'(3), 'Reiko'(4), 'Tsunokaori'(5), 'Harumi'(6), 'Harehime'(7), 'Amakusa'(8), 'Seihou'(9), and 'Akemi' (10); The arrow refers to the amplification profiles for the primers pMS33u+1462L in specific SCAR Fragments (1,429 bp). M: 1kbbp size marker.

cation of a specific DNA fragment [33].

In conclusion, BSA constructed three SRAP primer sets (F4/R27, F39/R60, and F15/R37) that were linked to male fertility in citrus. In addition, we were able to convert this SRAP into a dominant SCAR marker, pMS 33U/pMS 1462L. This SCAR marker can be efficiently used for MAS as expected a reduction of the probability of some false positives/-negatives of male fertile lines in citrus breeding programs.

\section{Acknowledgment}

This study was supported by the 2011 Post-Doctoral Course Program of the National Institute of Horticultural \& Herbal Science, Rural Development Administration, Republic of Korea.

\section{References}

1. Asins, M. J. 2002. Present and future of quantitative trait loci analysis in plant breeding. Plant Breeding 121, 281-291.

2. Bannerot, H., L. Boulidard, Y. Cauderon, and J. Tempé. 1974. Transfer of cytoplasmic male sterility from Rhaphanus sativus to Brassica oleracea. Proceedings Eucarpia Meeting Crop Section Cruciferae 25, 52-54.

3. Banno, K., H. Ishikawa, Y. Hamauzu, and H. Tabira, 1999. Identification of a RAPD marker linked to the susceptible gene of black spot disease in Japanese Pear. J. Japan Soc. Hort. Sci. 68, 476-481.

4. Budar, F. and G. Pelletier. 2001. Male sterility in plants: occurrence, determinism, significance and use. C.R. AcadSci. Paris, Sciences de la vie Life Sciences 324, 543-550.

5. Cao, Q. Q., H. J. Meng, X. P. Wen, H. L. Yi, and X. X. Deng. 2007. Genetic diversity of male sterile and low fertility germplasm of Citrus revealed using SSR markers. Chin. J. Agr. Biotechnol. 4, 99-104. 
6. Chase, C. D. 2006. Cytoplasmic male sterility: a window to the world of plant mitochondrial-nuclear interactions. Trends Genet. 23, 81-90.

7. Christopher, A. M. and J. D. Palmer. 1988. Mitochondrial DNA rearrangements and transcriptional alterations in the male-sterile cytoplasm of ogura radish. Mol. Cell Biol. 8, 1474-1480.

8. Dewey, R. E., C. S. Levings III, and D. H. Timothy. 1986. Novel recombinations in the maize mitochondrial genome produce a unique transcriptional unit in the Texas male-sterile cytoplasm. Cell 44, 439-449.

9. Fatta Del Bosco, S., M. Siragusa, L. Abbate, S. Lucretti, and N. Tusa. 2007. Production and characterization of new triploid seedless progenies for mandarin improvement. Scientia Horticulturae 114, 258-262.

10. Frost, H. B. 1948. Seed reproduction; development of gametes and embryos, pp. 767-816, In Webber H. J. and L. D. Batchelor (eds.), The Citrus Industry, Vol. 1. University of California Press, Berkley.

11. Guérin, G., E. Lerceteau - Kohler, F. Laigret, P. Roudeillac, and B. Denoyes - Rothan. 2003. Development of SCAR marker linked to dominant gene conferring resistance to Colletotrichum acutatum in strawberry. Acta Hort. 626, 85-91.

12. Gulsen, O., A. Uzun, I. Canan, U. Seday, and E. Canihos. 2010. A new citrus linkage map based on SRAP, SSR, ISSR, POGP, RGA and RAPD markers. Euphytica 173, 265-277.

13. Gutierres, S., M. Sabar, C. Lelandais, P. Chétrit, P. Diolez, H. Degand, M. Boutry, F. Vedel, Y. de Kouchkovsky, and R. de Paepe. 1997. Lack of mitochondrial and nuclear-encoded subunits of complex I and alteration of the respiratory chain in Nicotiana sylvestris mitochondrial deletion mutants. Proc. Natl. Acad Sci. 94, 3436-3441.

14. Hernandez, P., A. Martin, and G. Dorado. 1999. Development of SCARs by direct sequencing of RAPD products: a practical tool for the introgression and marker-assisted selection of wheat. Mol. Breed 5, 245-253.

15. Iwamasa, M. 1966. Studies on the sterility in genus Citrus with special reference to the seedlessness. Bulletin of the Horticultural Research Station 6, 1-81.

16. Jung, G., P. W. Skroch, J. Nienhuis, D. P. Coyne, E. Arnaud-Santana, H. M. Ariyarathne, and J. M. Marita. 1999. Confirmation of QTL associated with common bacterial blight resistance in four different genetic backgrounds in common bean. Crop Sci. 39, 1448-1455.

17. Kolosha, V. O. and I. Fodor. 1990. Nucleotide sequence of Citrus limon 26S rRNA gene and secondary structure model of its RNA. Plant Mol. Biol. 14, 147-161.

18. Laver, H. K., S. J. Reynolds, F. Moneger, and C. J. Leaver. 1991. Mitochondrial genome organization and expression associated with cytoplasmic male sterility in sunflower (Helianthus annuus). Plant J. 1, 185-193.

19. Levings, C. S. III. 1993. Thoughts on cytoplasmic male sterility in cms-T maize. Plant Cell 5, 1285-1290.

20. Li, G. and C. Quiros. 2001. Sequence-related amplified polymorphism (SRAP) a new marker system based on a simple PCR reaction: its application to mapping and gene tagging in Brassica. Theor. Appl. Genet. 103, 455-461.

21. Liu, Y. Z., X. T. Ma, H. Y. Zhang, S. Peng, and X. X. Deng. 2004. Status quo of Ponkan (Citrus reticulata Blanco) fruit quality and quality comparison between several production areas in China. Acta Hortic. Sin. 31, 584-588.

22. Matsumoto, R., N. Okudai, I. Oiyama, T. Takahara, M. Yamamoto, K. Asada, D. Ishiuchi, and H. Murata. 1991. New citrus cultivar 'Tsunokaori'. Bulletin of the Fruit Tree Research Station 21, 59-65.

23. Michelmore, R. W., I. Paran, and R. V. Kesseli. 1991. Identification of markers linked to disease-resistance genes by bulked segregant analysis: A rapid method to detect markers in specific genomic regions by using segregating populations. Proc. Natl. Acad Sci. 88, 9828-9832.

24. Nakamura, M. 1943. Cytological and ecological studies on the genus Citrus, with special reference to the occurrence of sterile pollen grains. Mem Fac. Sci. Agr. Taihoku Imp. Univ. 27, 53-159.

25. Nakano, M., H. Nesumi, T. Yoshioka, and T. Yoshida. 2001. Segregation of plants with undeveloped anthers among hybrids derived from the seed parent, 'Kiyomi' (Citrus unshiu x C. sinensis). J. Japan Soc. Hort. Sci. 70, 539-545.

26. Nesumi, H., M. Nakano, T. Yoshida, T. Yoshioka, and Y. Ito. 1997. Effect of Plasmon on segregation of male sterile traits in citrus. J. Japan. Soc. Hort. Sci. 66, 164-165

27. Nishiura, M., T. Shichijo, I, Ueno, M. Iwamasa, T. Kihara, Y. Yamada, T. Yoshida, and T. Iwasaki. 1983. New citrus cultivar 'Kiyomi' tangor. Bulletin of the Fruit Tree Research Station 10, 1-9.

28. Nivison, H. T. and M. R. Hanson. 1989. Identification of a mitochondrial protein associated with cytoplasmic male sterility in Petunia. Plant Cell 1, 1121-1130.

29. Ogura, H. 1968. Studies on the new male-sterility in Japanese radish with special reference to the utilisation of this sterility towars the practical raising of hybrid seeds. Mem Fac. Agric. Kagoshima Univ. 6, 39-78.

30. Ollitrault, P., F. Luro, and M. Yamamoto. 2007. Seedlessness and ploidy manipulations pp. 197-218, In Khan, I. A. (eds), Citrus Genetics, Breeding and Biotechnology. CAB International UK.

31. Paran, I. and R. W. Michelmore. 1993. Development of reliable PCR-based markers linked to downy mildew resistance genes in lettuce. Theor. Appl. Genet. 85, 985-993.

32. Raza, H., M. M. Khan, and A. A. Khan. 2003. Seedlessness in citrus. Int. J. Agr. Biol. 5, 388-391.

33. Rugienius, R., T. Siksnianas, V. Stanys, D. Gelvonauskiene, and V. Bendokas. 2006. Use of RAPD and SCAR markers for identification of strawberry genotypes carrying red stele (Phytophtora fragariae) resistance gene Rpf1. Agronomy Res. 4, 335-339.

34. Shen, D. X., Y. Y. Wang, and L. G. Chen. 1998. Genetic breeding of citrus. pp. 161-166, Beijing Science Press.

35. Sun, S. J., W. Gao, S. Q. Lin, J. Zhu, B. G. Xie, and Z. B. Lin. 2006. Analysis of genetic diversity in Ganoderma population with a novel molecular marker SRAP. Appl. Microbiol. Biotechnol. 72, 537-543. 
36. Uzun, A., T. Yesiloglu, Y. Aka-Kacar, O. Tuzcu, and O. Gulsen. 2009. Genetic diversity and relationships within Citrus and related genera based on sequence related amplified polymorphism markers (SRAPs). Scientia Horticulturae 121, 306-312.

37. Vardi, A. and P. Spiegel - Roy. 1978. Citrus breeding, taxonomy and species problems. Proc. Int. Soc. Citriculture 184, 51-57.

38. Vos, P., R. Hogers, M. Bleeker, M. Reijans, T. Van de lee, M. Hornes, A. Frijters, J. Pot, J. Peleman, M. Kuiper, and M. Zabeau. 1995. AFLP: a new technique for DNA fingerprinting. Nucl. Acids Res. 23, 4407-4414.

39. Williams, J. G. K., A. R. Kubelik, K. J. Livak, J. A. Rafalski, and S. V. Tingey. 1990. DNA polymorphisms amplified by arbitrary primers are useful as genetic markers. Nucleic Acids Res. 18, 6531-6535.

40. Xiao, J. P., L. G. Chen, M. Xie, H. L. Liu, and W. Q. Ye. 2009. Identification of AFLP fragments linked to seedlessnes $\mathrm{s}$ in Ponkan mandarin (Citrus reticulata Blanco) and con- version to SCAR markers. Scientia Horticulturae 121, 505-510.

41. Yamamoto, M., N. Okudai, and R. Matsumoto. 1992. Segregation for aborted anthers in hybrid seedlings using Citrus nobilis $\times C$. deliciosa cv. Encore as the seed parent. J. Japan Soc. Hort. Sci. 60, 785-789.

42. Yamamoto, M., N. Okudai, and R. Matsumoto. 1992. Study on the inheritance of aborted anthers in citrus using seed parents having aborted anthers. J. Japan Soc. Hort. Sci. 60, 791-797.

43. Yamamoto, M., R. Matsumoto, N. Okudai, and Y. Yamada. 1997. Aborted anthers of Citrus result from gene-cytoplasmic male sterility. Scientia Horticulturae 70, 9-14.

44. Yamamoto, M., Y. Yamada, R. Matsumoto, H. Ikemiya and N. Okudai. 1992. Inheritance of seed number in citrus. Bulletin of the Fruit Tree Research Station 23, 47-56.

45. Yamasaki, A., A. Kitajima, N. Ohara, M. Tanaka, and K. Hasegawa. 2009. Characteristics of arrested seeds in Mukaku Kishu-type seedless Citrus. J. Japan Soc. Hort. Sci. 78, 61-67.

\section{초록 : '진귤' (Citrus sunk) 의 웅성가임 연관 SCAR 마커 개발}

채치원 ${ }^{1} \cdot$ Manjul Dutt ${ }^{2} \cdot$ 윤수현 $^{1} \cdot$ 박재호 ${ }^{1} \cdot$ 이동훈 $^{1}$ *

('국립원예특작과학원 감귤시험장, ${ }^{2}$ 플로리다 대학교 감귤연구 교육센터)

감귤류 중 수술이 퇴화되어 웅성불임형질을 나타내는 '청견' 품종에 정상적인 수술의 형태를 가진 웅성가임인 '진귤' 품종을 교배하여 150 개체의 $\mathrm{F}_{1}$ 집단을 구축하여 수술이 퇴화되는 개체와 정상인 개체를 분리하였다. 분리 된 $\mathrm{F}_{1}$ 개체들을 사용하여 SRAP 기법과 집단 분리 분석법(BSA)을 조합하여 웅성 가임 연관 마커 개발에 활용하였 다. F1 집단 내 150 개체 중 66 개체가 퇴화 수술을 갖고 있으며 웅성 가임성과 웅성 불임성의 분리비는 1:1이며 $x^{2}$ 값은 2.16( $\left.p=0.05\right)$ 이었다. 197개의 SRAP 프라이머 조합들 중 웅성가임 특이밴드를 형성하는 3개의 SRAP 프라 이머 조합(F4/R27, F39/R60, 및 F15/R37)을 선발하였으며, 이 중 F39/R60 프라이머에 특이적으로 증폭하는 $\mathrm{DNA}$ 단편의 염기서열을 기본으로 하여 새롭게 작성한 양방향 프라이머 조합 중 웅성 가임 계통에서만 약 1.4 $\mathrm{Kb}$ 의 특이밴드를 증폭하는 프라이머 조합, $\mathrm{pMS} \mathrm{33U/pMS} 1462 \mathrm{~L}$ 를 선발하여 SCAR 마커를 개발 하였다. 이러한 결과는 개발된 SCAR 마커로 무핵성 계통들의 육종 선발에 효율성을 높일 수 있을 것으로 기대된다. 